\title{
DIAGNOSIS OF PULMONARY PNEUMOCYSTOSIS BY MICROSCOPY ON WET MOUNT PREPARATIONS
}

Amadeo Javier BAVA, Sylvia CATTÁNEO \& Enrique BELLEGARDE

\section{SUMMARY}

We have compared the searching of the presence of "honeycomb" structures by direct microscopy on wet mount preparations with the direct immunofluorescence (DIF) for the diagnosis of Pneumocystis carinii pneumonia (PCP) in 115 bronchoalveolar (BAL) fluids. The samples belonged to 115 AIDS patients; 87 with presumptive diagnosis of PCP and 28 with presumptive diagnosis other than PCP.

The obtained results were coincident in 114 out of 115 studied samples ( 27 were positive and 87 negative) with both techniques. A higher percentage of positive results $(32.18 \%)$ among patients with presumptive diagnosis of PCP with respect to those with presumptive diagnosis other than PCP (3.57\%) was observed. One BAL fluid was positive only with DIF, showed scarce and isolated $P$. carinii elements and absence of typical "honeycomb" structures.

The searching for "honeycomb" structures by direct microscopy on wet mount preparations could be considered as a cheap and rapid alternative for diagnosis of PCP when other techniques are not available or as screening test for DIF. This method showed a sensitivity close to DIF when it was applied to BAL fluids of AIDS patients with poor clinical condition and it was performed by an experienced microscopist.

KEYWORDS: PCP; Pneumocystosis; Diagnosis of PCP and wet mount microscopy.

\section{INTRODUCTION}

Pneumocystis carinii pneumonia (PCP) is a frequent opportunistic infection among AIDS patients. HIV infected patients are at high risk of developing PCP when the CD4+ count is below $250 / \mathrm{mm}^{3}{ }^{7}$.

The presumptive diagnosis of PCP is usually based on clinical (dyspnea, non-productive cough and fever), radiological (diffuse bilateral interstitial infiltrate) and laboratory (hypoxia revealed by arterial blood gases and low CD4+ lymphocyte count) findings ${ }^{8}$.

Diagnostic confirmation of PCP is achieved by microscopic detection of $P$. carinii in respiratory specimens taken by expectoration, induced sputum, open-lung biopsy, transbronchial biopsy, bronchoscopy or bronchoalveolar lavage. This latter is considered as the clinical sample of choice for the investigation of this infection ${ }^{6}$.

Stains such as Gomori's methenamine silver and Toluidine blue $\mathrm{O}$ for cysts and Giemsa for trophozoites of $P$. carinii, can be performed on smears of respiratory specimens ${ }^{2,4}$. Direct immunofluorescence (DIF) employing monoclonal antibodies against major cell wall and surface antigens of $P$. carinii is more sensitive and specific than the techniques mentioned above and detects both cysts and trophozoites ${ }^{5}$.

The finding in the alveoli of a hyaline foamy granular eosinophilic exudate with a "honeycomb" aspect on examination of lung sections stained with haematoxylin and eosin is a common criterion employed by pathologists for the recognition of $\mathrm{PCP}^{3}$. Nevertheless, the diagnosis of PCP based on finding the characteristic "honeycomb" structures by direct microscopy on wet mounts of respiratory samples is not widely considered among the diagnostic methods ${ }^{2,4}$.

The aim of this work was to compare the usefulness of the search of "honeycomb" structures by microscopy on wet mount preparations in the diagnosis of PCP with the DIF in BAL fluids from AIDS patients admitted in different wards of the Muñiz Hospital of Buenos Aires.

\section{MATERIALS AND METHODS}

From April 2000 to January 2001, we have studied 87 consecutive 
BAL fluid samples sent to our laboratory for investigation of $P$. carinii by direct microscopy on wet mount preparations and DIF. The specimens belonged to AIDS patients hospitalized in different wards of the Muñiz Hospital with presumptive diagnosis of PCP.

Additionally, as a control, we have studied, using the same methodology, other 28 consecutive samples of BAL fluids from AIDS patients with presumptive diagnosis other than PCP submitted to the Laboratory of Bacteriology of the Muñiz Hospital from January 2001 to February 2001.

The BAL fluids were centrifuged in plastic tubes with screw cap at 3,000 rpm for 10 minutes. A drop of the sediment was placed on glass slide, under a $24 \times 32 \mathrm{~mm}$ coverslip, for the wet mount microscopy and another drop was placed on immunofluorescence glass slide to perform the DIF.

The DIF technique was performed and the results were interpreted according to the instructions of the manufacturer (Merifluor-Pneumocystis. Meridian. Diagnostics, Inc. Cincinnati, Ohio, USA). In brief, a drop of the clinical sample sediment fixed with acetone to an immunofluorescence slide was incubated at $37^{\circ} \mathrm{C}$ in humidity chamber for 30 minutes with the detection reagent. This latter contains fluorescein isothiocyanate labeled monoclonal antibodies directed against surface antigens of $P$. carinii and Evans blue. For DIF lecture, it was employed a epifluorescence microscope (Alphaphot 2 YS2H model, Nikon, Japan) equipped with a filter systems for fluorescein isothiocyanate with excitation wavelength at 490-500 nm and barrier filter at $510-530 \mathrm{~nm}$. As control, a positive BAL sample belonging to an AIDS patient previously diagnosed as PCP with DIF was included in each determination.

In the microscopy on wet mount preparations the samples were considered positive when "honeycomb" structures (Fig. 1 to 3) were observed with low power (100x), high - dry (400x) and/or oil immersion $(1,000 \mathrm{x})$ magnification in a light microscope $(\mathrm{CH} 30$ model, Olympus, Japan). The whole coverslip surface was examined before scoring a sample as negative.

\section{RESULTS}

Microscopic examination by microscopy on wet mount preparations of the samples resulted in the detection of the "honeycomb" structures in 27 cases of suspected PCP and 1 case with other presumptive diagnosis, as shown in Table 1. Accumulative results are summarized in Table 1.

A correlation between results obtained with DIF and microscopy on wet mount preparations was observed in 114 (99.13\%) out of the 115 studied BAL fluids: 27 studies were positive and 87 negative.

One clinical sample belonging to an AIDS patient with presumptive diagnosis of PCP was only positive with DIF. It showed scarce and fluorescent round microorganisms and absence of typical "honeycomb" structures.

Other BAL fluid, belonging to a patient with presumptive diagnosis other than PCP, was positive with both techniques. In this patient, the presumptive diagnosis was later considered to be a mistake and in retrospective analysis this patient was diagnosed as PCP.

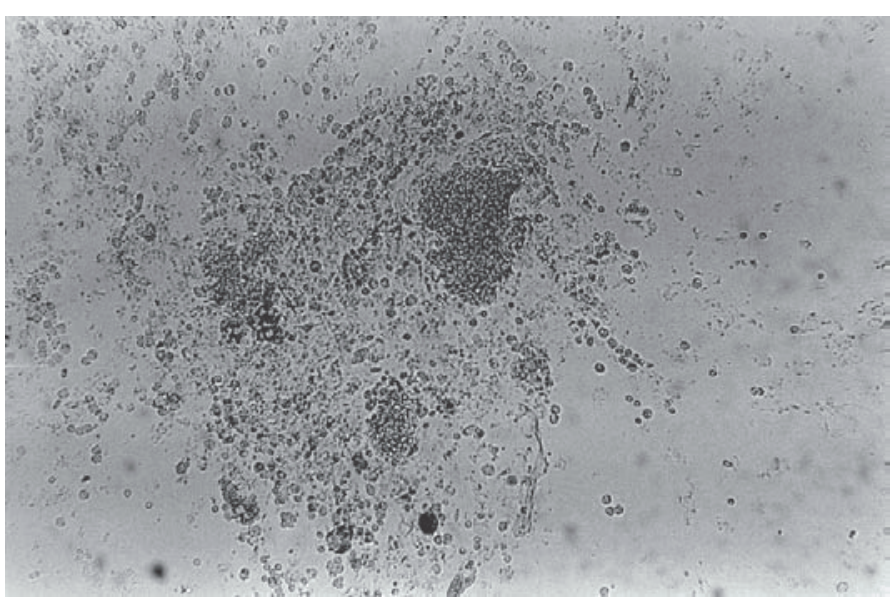

Fig. 1 - "Honeycomb structures" by wet mount microscopy of BAL fluid sample with low power magnification $(100 \mathrm{x})$.

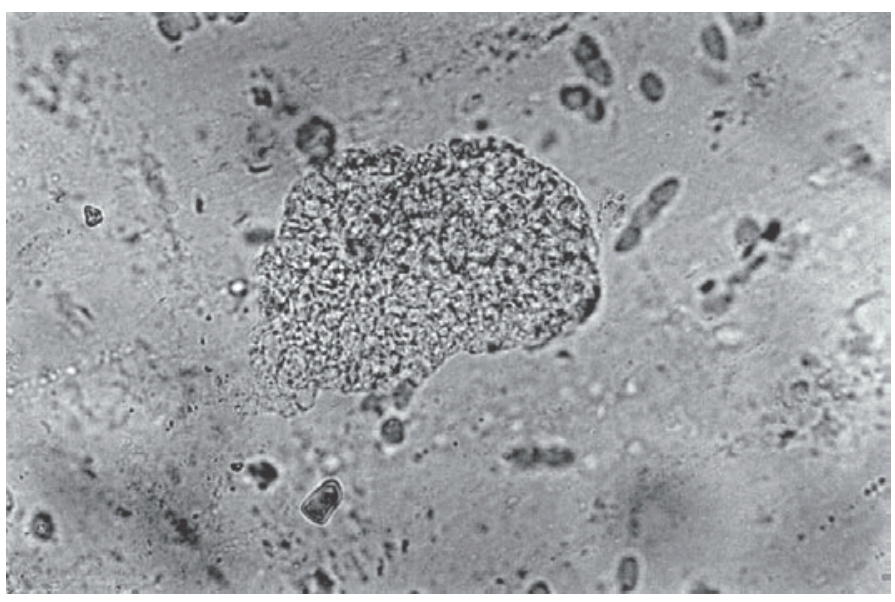

Fig. 2 - "Honeycomb structure" by wet mount microscopy of BAL fluid sample with highdry magnification (400x).

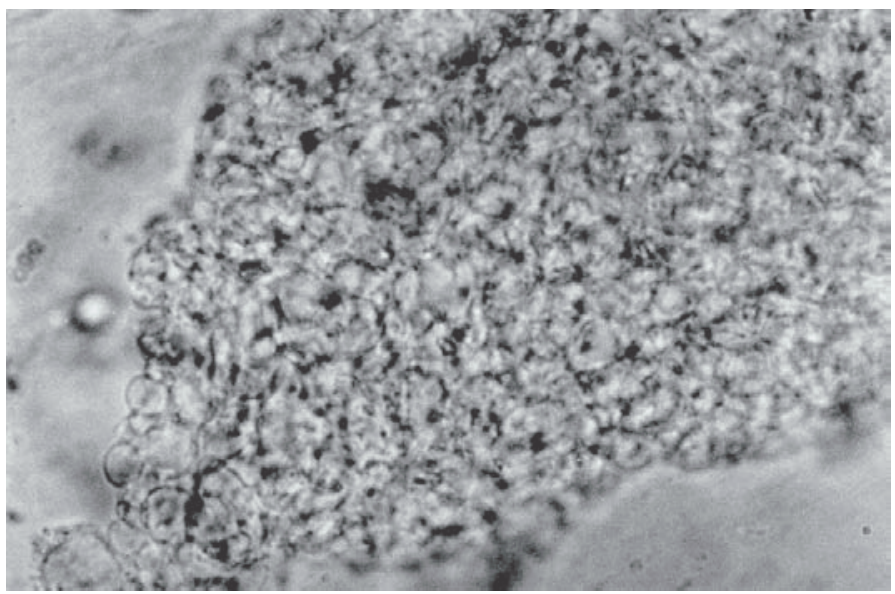

Fig. 3 - "Honeycomb structure" by wet mount microscopy of BAL fluid sample with oil immersion (1,000x). 


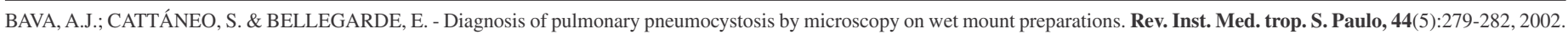

Table 1

Results of the direct microscopy on wet mount and direct immunofluorescence (DIF) for the diagnosis of PCP, applied to 115 BAL fluid samples from AIDS patients hospitalized in the Muñiz Hospital with presumptive diagnosis of PCP or presumptive diagnosis other than PCP

\begin{tabular}{|c|c|c|c|c|c|c|c|c|}
\hline \multirow{3}{*}{$\begin{array}{l}\text { Technique of diagnosis } \\
\text { Result }\end{array}$} & \multicolumn{4}{|c|}{ Direct immunofluorescence } & \multicolumn{4}{|c|}{ Wet mount microscopy } \\
\hline & \multicolumn{2}{|c|}{ Positive } & \multicolumn{2}{|c|}{ Negative } & \multicolumn{2}{|c|}{ Positive } & \multicolumn{2}{|c|}{ Negative } \\
\hline & $\mathrm{N}$ & $\%$ & $\mathrm{~N}$ & $\%$ & $\mathrm{~N}$ & $\%$ & $\mathrm{~N}$ & $\%$ \\
\hline Presumptive diagnosis of PCP $(\mathrm{n}=87)$ & 28 & 32.18 & 59 & 67.82 & 27 & 31.03 & 60 & 68.96 \\
\hline Presumptive diagnosis other than PCP $(\mathrm{n}=28)$ & 1 & 3.57 & 27 & 96.43 & 1 & 3.57 & 27 & 96.43 \\
\hline Total $(\mathrm{n}=115)$ & 29 & 25.22 & 86 & 74.78 & 28 & 24.35 & 87 & 75.65 \\
\hline
\end{tabular}

PCP: Pneumocystis carinii pneumonia; N: number of cases.

A higher percentage of positive results was obtained from BAL fluids belonging to AIDS patients with presumptive diagnosis of $\mathrm{PCP}(32.18 \%)$ with respect to those with presumptive diagnosis other than PCP $(3.57 \%)$. The difference between both values was statistically significant when was analyzed with the contingency tables (chi square) $(\mathrm{p}=0.025)$.

\section{DISCUSSION}

Traditional picture of PCP in histopathological sections of lung is characterized by a foamy intra-alveolar exudate which is removed by the BAL proceeding from the affected alveoli. This exudate is microscopically observed in the BAL fluid as hyaline and pleomorphic masses with net limits and variable size $(50 \mu \mathrm{m}-500 \mu \mathrm{m}$ or more) showing little and rounded spaces in the whole structure. These latter are more evident in wet mount preparations when the periphery of the "honeycomb" structure is observed with high magnification (Fig. 3). Cysts and trophozoites of $P$. carinii, eventually present into this structure, are stained with the different techniques mentioned above $e^{2,4,5}$.

In spite of the reported absence of alveolar exudate with "honeycomb" forms in about $20-40 \%$ of AIDS patients with $\mathrm{PCP}^{7}$, the results obtained in the present study suggest a probable usefulness of the microscopic recognition on wet mount preparations of these structures for the diagnosis of PCP. Indeed, these structures are also observed when the DIF is applied on clinical samples for the diagnosis of PCP, as can be seen even in the instructions of the commercial kit.

In a previous double-blind study, we compared the sensitivity and specificity of the direct microscopy on wet mount preparations and DIF in the diagnosis of PCP, performed both on BAL fluids from AIDS and nonAIDS patients. We obtained a sensitivity of about $80 \%$ for the wet mount microscopy respect to DIF. This relatively low value may be probably the result of the lack of experience of the microscopist in the early phase of the study, when most of the false positive and false negative results occur ${ }^{1}$.

The results obtained in the present study showed a sensitivity of the direct microscopy on wet mount preparations close to that of the DIF, considered as the most sensitive and specific technique for the diagnosis of PCP. Nevertheless, this technique was applied by previously trained microscopists on BAL fluids belonging to gravely ill AIDS patients. Probably the high "microbial burden" present in the clinical samples of AIDS patients with poor clinical and immunological conditions contributed for the easy detection of "honeycomb" structures in the microscopy on wet mount preparations.

Recognition of "honeycomb" structures by microscopy on wet mount preparations seems to be in our experience strongly influenced by the training of the microscopists. Non-trained microscopists found it difficult to detect these structures, although they recognize them easily when shown by a senior observer.

We have taught to inexperienced microscopists to recognize "honeycomb" structures by microscopic examination from a proven positive control, either, on wet mount preparations and DIF. After one month of intensive training they recognize without difficulties the "honeycomb" structures in clinical samples.

"Honeycombs" structures could be mistaken in wet mount preparations with artifacts (cellular detritus or microbial or cellular clusters) when they are microscopically observed with low power by inexperienced microscopists (Fig. 1). This mistake can be corrected by the visualization of these structures with a more powerful objective (highdry magnification or oil immersion), as shown in Fig. 2 and 3.

As a routine, we also perform the Toluidine blue $\mathrm{O}$ and Giemsa stains to detect respectively cysts and trophozoites of $P$. carinii in all clinical samples, including sputum, pulmonary biopsies and BAL when they were negative with microscopy on wet mount preparations. Gomori's methenamine silver technique is not employed because it is time consuming, needs many and expensive reagents and it has lower sensitivity than DIF because it only stains cysts.

Additionally, better results were not obtained using dark field and phase-contrast microscopy with respect to bright-field microscopy in the search of the "honeycomb" structures in wet mount preparations of the BAL samples.

For samples belonging to AIDS patients highly suspicious of PCP with negative results for wet mount microscopy and the above-mentioned stains for cysts and trophozoites, we employ the DIF.

Other more sensitive methods for the diagnosis of PCP than DIF, as DNA hybridization techniques, using the polymerase chain reaction and oligonucleotide probes, have been developed in the last years. These methods, only available in developed countries, deserve further evaluations ${ }^{2}$. 
The visualization of "honeycomb" structures by microscopy on wet mount preparations for diagnosis of PCP was, in our hands, easy to perform, cheap and the results were obtained quickly, with a correlation near to $100 \%$ with those obtained with the DIF. Moreover, it required an experienced microscopist and the results above mentioned were produced only when it was applied on BAL fluids obtained from severely ill AIDS patients with presumptive diagnosis of PCP.

BAL is routinely employed in AIDS patients admitted in our center for the diagnosis of pulmonary pathology, when it is possible to perform, according to the patients clinical condition. Thus, this technique should not add additional costs to the diagnosis of PCP by microscopy on wet mount preparations.

The search of "honeycomb" structures by microscopy on wet mount preparations could be considered as screening for DIF test or as a alternative in the diagnosis of PCP, when other methods are not available. This consideration can be especially relevant for undeveloped countries and deserves further attention.

\section{RESUMO}

\section{Diagnóstico de pneumocistose pulmonar a microscopia a fresco}

Comparamos a presença de estruturas com aspecto de "favo de mel" através da microscopia a fresco e imunofluorescência direta (IFD) no diagnóstico de pneumocistose pulmonar ( $P$. carinii) (PCP) em secreções do aparelho respiratório obtidas através do lavado bronco-alveolar (BAL) de 115 pacientes com AIDS. Oitenta e sete amostras pertenciam a pacientes com diagnóstico presuntivo de PCP e 28 a pacientes com outros diagnósticos diferentes de PCP.

Os resultados obtidos foram coincidentes em 114 das 115 amostras pesquisadas ( 27 foram positivas e 87 negativas) com porcentagem mais elevada de resultados positivos entre os pacientes com diagnóstico presuntivo de PCP $(32,18 \%)$ do que entre aqueles com outros diagnósticos presuntivos $(3,57 \%)$. Um BAL $(1,14 \%)$ foi positivo somente com a IFD que revelou poucas formas isoladas de $P$. carinii e ausência das estruturas típicas com aspecto de "favo de mel".

A pesquisa de estruturas com aspecto de "favo de mel" através da microscopia a fresco poderia ser considerada como um método alternativo, econômico e rápido, para o diagnóstico de $\mathrm{PCP}$, quando outras técnicas não estiverem disponíveis ou como prova de "screening" prévia antes do DIF. Esse método demonstrou sensibilidade semelhante a DIF aplicada em secreções do aparelho respiratório obtidas através do BAL em pacientes com AIDS com más condições clínicas quando executada por um microscopista experiente.

\section{ACKNOWLEDGEMENTS}

We are indebted to Roberto A. Diez, MD for helpful discussion, and Mr. Sidney Soares de Souza and Marcela Witt for review of the Portuguese and English language, respectively.

\section{REFERENCES}

1. BAVA, A.J.; CASTRO ZORRILLA, L.; TRONCOSO, D. et al. - Empleo de la microscopía en fresco en el diagnóstico de la neumocistosis. Rev. argent. Infect., 10: 12-15, 1997.

2. CUSHION, M.T. - Pneumocystis carinii. In: AJELLO, L. \& HAY, R.J., ed. Topley \& Wilson's microbiology and microbial infections. 9. ed. London, Arnold, 1998. v. 4, p. 645-683.

3. FUJIOKA, H. \& AIKAWA, M. - Pneumocystosis. In: COX, F.E.G.; KREIER, J.P. \& WAKELIN, D. Topley \& Wilson's microbiology and microbial infections., 9. ed. London, Arnold, 1998. v. 5, p. 431-444.

4. HADLEY, W.K. \& NG, V. - Pneumocystis. In: MURRAY, P.R.; BARON, E.J.; PFALLER, M.A.; TENOVER, F.C. \& YOLKEN, R.H., ed. Manual of clinical microbiology. 6. ed. Washington, ASM Press, 1995. p. 738-748.

5. KOVACKS, J.A.; NG, V.; MASUR, H. et al. - Diagnosis of Pneumocystis carinii pneumonia: improved detection in sputum with use of monoclonal antibodies. New Engl. J. Med., 318: 589-593, 1988.

6. OGNIBENE, F.P.; SHELHAMER, J.; GILL, V. et al. - The diagnosis of Pneumocystis carinii pneumonia in patients with the acquired immunodeficiency syndrome using subsegmental bronchoalveolar lavage. Amer. Rev. resp. Dis., 129: 929-932, 1984.

7. PHAIR, J.; MUÑOZ, A.; DETELS, R. et al. - The rise of Pneumocystis carinii pneumonia among men infected with human immunodeficiency virus type 1. Multicenter AIDS cohort study group. New Engl. J. Med., 322: 161-165, 1990.

8. WALZER, P.D. - Pneumocystis carinii. In: MANDELL, G.L.; BENNETT, J.E. \& DOLIN, R., ed. Principles and practice of infectious diseases. 4. ed. New York, Churchill Livingstone, 1995. p. 2475-2487.

Received: 01 October 2001

Accepted: 03 July 2002 